\title{
Detection of Meloidogyne graminicola parasitising Cyperus rotundus in Rio Grande do Sul, Brazil
}

\author{
Cristiano Bellé ${ }^{1}$ (I) $\cdot$ Tiago Edu Kaspary $^{2} \cdot$ Ricardo Rubin Balardin $^{1} \cdot$ Zaida Ines Antoniolli $^{1}$
}

Received: 19 October 2018 / Accepted: 26 December 2018 / Published online: 7 January 2019

(C) Australasian Plant Pathology Society Inc. 2019

\begin{abstract}
Cyperus rotundus plants showing symptoms of root knot were observed in the municipality of Santa Maria, Rio Grande do Sul state, Brazil. Based on the morphological, esterase phenotypes and molecular analyses of rDNA-ITS and D2-D3 regions of 28S rDNA, the causal agents of the observed symptoms were identified as Meloidogyne graminicola, pathogenicity was confirmed by fulfilling Koch's postulates. To our knowledge, this is the first report of M. graminicola in C. rotundus in Rio Grande do Sul State, Brazil.
\end{abstract}

Keywords Occurrence $\cdot$ Identification $\cdot$ Root-knot nematodes $\cdot$ Purple nutsedge

Weeds reduce agricultural productivity by competing for environmental resources, allelopathic effects and serving as alternative hosts for pests and pathogens (Webster and Nichols 2012; Bellé et al. 2017). Cyperus rotundus (purple nutsedge) is a cosmopolitan weed species found in tropical and temperate areas, occurring as in many countries worldwide. The purple nutsedge is a persistent and herbaceous weed, being perennial of multiple crops throughout the world with the primarily reproduces vegetatively via rhizomes and tubers, though it will flower and produce seed.

The $C$. rotundus is among one of the most difficult weeds to control in main summer crops such as sugarcane, pulses, cotton, maize, rice and horticultural crops due to its tolerance of many control practices, including many herbicides (Webster and Nichols 2012). The absence to control of purple nutsedge occurs because of the longevity of tubers, capability to germinate many times, modes of multiple promulgation and unavailability of herbicides for season long control (Iqbal et al. 2018). C. rotundus may serve as an alternative host for many crop pests including arthropods, diseases and nematodes (Peerzada 2017).

Cristiano Bellé

crbelle@gmail.com

1 Departamento de Solos, Centro de Ciências Rurais, Universidade Federal de Santa Maria, Santa Maria, RS 97105900, Brazil

2 Instituto Nacional de Investigación Agropecuaria, INIA La Estanzuela, 70000 Colonia, Uruguay
In April 2018, samples of purple nutsedge plants (Fig. 1a, b) exhibiting many galls on the roots (Fig. 1) were observed, with representative samples taken from areas in the Santa Maria

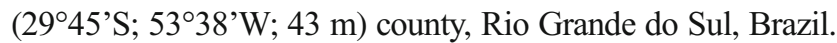

The identification to species of the Meloidogyne population was carried out using esterase phenotypes ( $n=40$ females) (Carneiro et al. 2000; Carneiro and Almeida 2001), morphological measurement of second-stage juveniles (J2) $(n=50)$, females $(n=20)$ and males $(n=10)$, and perineal patterns $(n=20)$ and via the amplification and sequencing of the ITS1-5.8S-ITS2 rRNA region (primer set: forward 5'-TTGATTACGTCCCT GCCCTTT-3' and reverse 5'-TCCTCCGCTAAATGATATG$3^{\prime}$ ) and the D2-D3 fragment of the 28S rRNA gene (primer set: forward 5'-ACAAGTACCGTGAGGGAAAGTTG-3' and reverse 5'-TCGGAAGGAACCAGCTACTA-3') (Schmitz et al. 1998; De Ley et al. 1999).

After the extraction of adult females, the total nematode population was estimated per gram of purple nutsedge roots (Hussey and Barker 1973). Microscope slides of perineal patterns were deposited (LB0012) in the Universidade Federal de Santa Maria (UFSM) Collection, Rio Grande do Sul state, Brazil.

The nematode population density observed in the sample was $785 \mathrm{~J} 2 \mathrm{~s} / \mathrm{g}$ of $C$. rotundus root. The $\mathrm{J} 2 \mathrm{~s}$ had the following morphometric characters: length $(\mathrm{L})=482.5 \pm 30.0$ (385.0 479.5) $\mu \mathrm{m}, \mathrm{a}=27.1 \pm 1.3$ (24.4-29.0), $\mathrm{c}=5.5 \pm 0.5$ (5.0 7.3), stylet length $=14.5 \pm 0.4(13.1-15.9) \mu \mathrm{m}$, dorsal oesophageal gland orifice $(\mathrm{DGO})=3.5 \pm 0.7(3.2-4.7) \mu \mathrm{m}$, tail length $=71.6 \pm 4.1(62.0-75.9) \mu \mathrm{m}$ and hyaline tail terminus $=18.5 \pm 1.4(15.6-24.7) \mu \mathrm{m}$. Morphological 
Fig. 1 Meloidogyne graminicola root infestation symptoms on purple nutsedge (Cyperus rotundus)

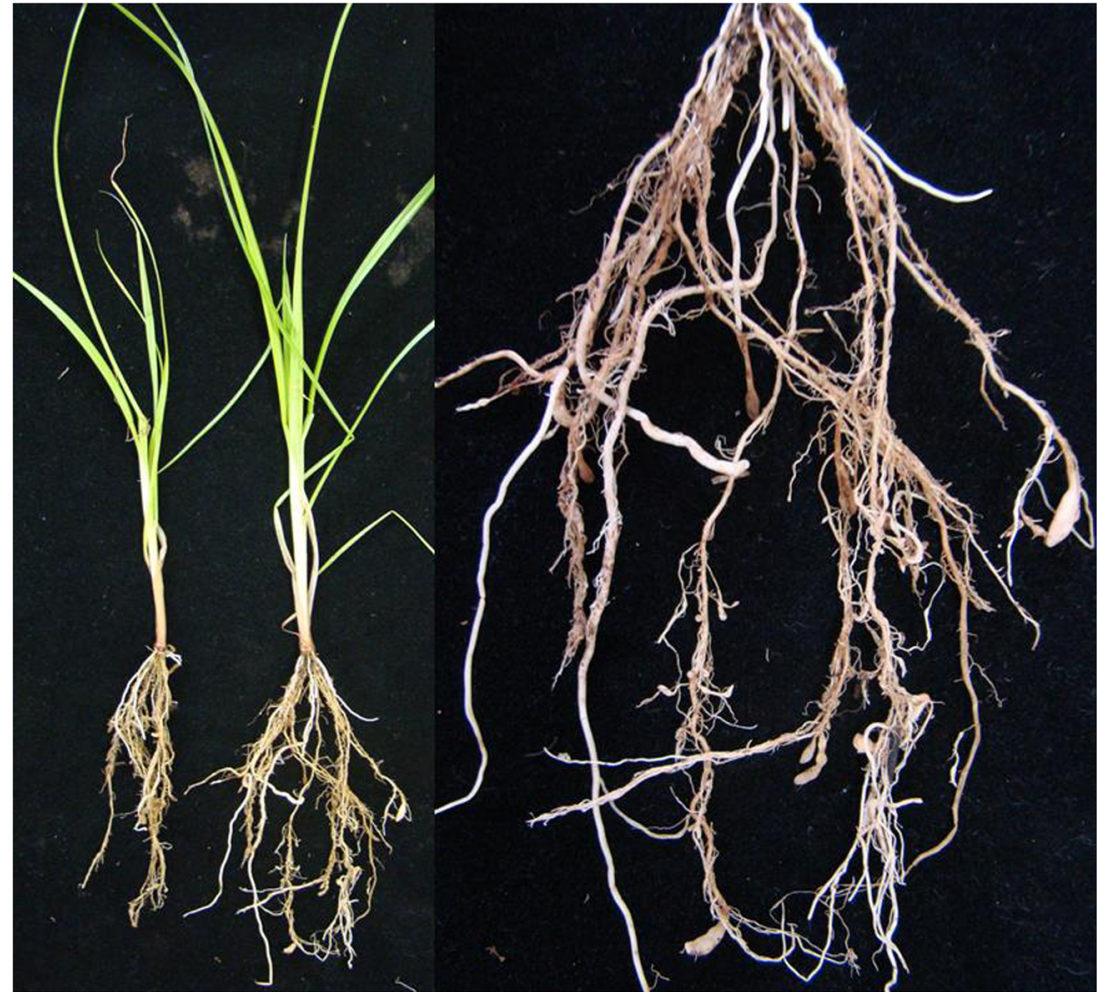

measurements of females included $\mathrm{L}=650.5 \pm 50.6$ (510.7723.8) $\mu \mathrm{m}$, stylet length $=13.1 \pm 0.8(11.5-14.9) \mu \mathrm{m}$, and $\mathrm{DGO}=3.8 \pm 0.5(3.2-5.2) \mu \mathrm{m}$. The female's perineal patterns (Fig. 2a, b) were oval shape and a low dorsal arch without the presence of a lateral line and the cuticular striations were smooth and thick in the dorsal region of the vulva and phasmids were close together $(13,1$ to $17.9 \mu \mathrm{m})$. The males were cylindroid and vermiform with a robust stylet, arcuate spicule, and short and rounded tail. Measurements of males were $\mathrm{L}=$ $1305.8 \pm 130.5(1155.1-1602.1) \mu \mathrm{m}$, stylet length $=19.1 \pm 0.8$ (17.1 to 19.4$) \mu \mathrm{m}, \mathrm{DGO}=3.7 \pm 0.6(2.5$ to 4.1$) \mu \mathrm{m}$, tail $=$ $11.2 \pm 1.9$ (9.5 to 14.7$) \mu \mathrm{m}$, spicule $=31.5 \pm 1.8(28.1-35.4)$ $\mu \mathrm{m}$. The overall morphology and morphometrics of the population of $M$. graminicola correspond well with the original description (Golden and Birchfeild 1965).
The polymorphisms of the esterase bands by electrophoresis revealed the phenotype VS-1 $(\mathrm{Rm}=0.70)$ typical of M. graminicola (Carneiro et al. 1996) (Fig. 2c). The sequences of the studied rDNA regions were submitted to GenBank (ITS: MH842692 and D2-D3 of 28S: MH843665). Searches on BLAST showed $99 \%-100 \%$ identity with sequences of M. graminicola isolates from Brazil, Taiwan and China.

In greenhouse tests, $C$. rotundus plantlets were maintained in pots with $2000 \mathrm{~cm}^{3}$ sterilised soil. Six replicates were inoculated with 5000 eggs and $\mathrm{J} 2 \mathrm{~s}$ from the original population of M. graminicola, in addition to a non-inoculated control. Plants were maintained under greenhouse conditions at $25-30{ }^{\circ} \mathrm{C}$, with watering as needed. After 55 days, the inoculated plants exhibited galled root systems similar to plants observed in the field; the nematode reproduction factor (final population/

Fig. 2 Perineal pattern (a and b), and esterase phenotype (c) of Meloidogyne graminicola detected in Cyperus rotundus in Santa Maria, Rio Grande do Sul state, Brazil (VS1: Meloidogyne graminicola; Est. J3*:

Meloidogyne javanica reference isolate)
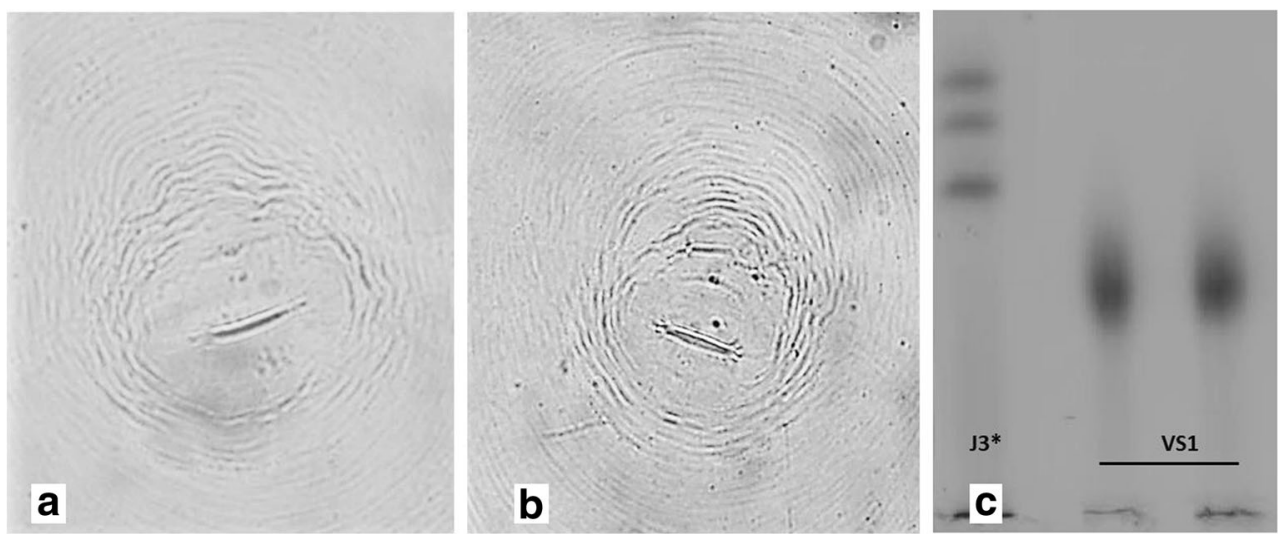
initial population) was 12.5 . The non-inoculated plants did not exhibit any galls. The morphological and molecular characteristics of the re-isolated root-knot nematode were identical those of M. graminicola.

To our knowledge, this is the first report of $M$. graminicola parasitising C. rotundus in Brazil. Globally, M. graminicola is considered an economically important agricultural nematode as it causes severe yield losses to crops such as rice, is reported to infect over 100 plant species, including cereals and grass plants, as well as dicotyledonous plants (Mantelin et al. 2017). This record has significance for rice production in Brazil as the weed $C$. rotundus could act as a potential reservoir for $M$. graminicola in the absence of host crops and necessitate study of its biology to aid the development of appropriate control strategies that minimize its effect on crop production.

Acknowledgements The present work was carried out with the support of CNPq, National Council of Scientific and Technological Development - Brazil (n 152757/2018-0).

\section{References}

Bellé C, Kaspary TE, Kuhn PR, Schmitt J, Lima-Medina I (2017) Reproduction of Pratylenchus zeae on weeds. Planta Daninha 35: e017158528. https://doi.org/10.1590/s0100-83582017350100006

Carneiro RMDG, Almeida MRA (2001) Técnica de eletroforese usada no estudo de enzimas dos nematoides de galhas para identificação de espécies. Nematologia Brasileira 25:555-560
Carneiro RMDG, Almeida MRA, Carneiro RG (1996) Enzyme phenotypes of Brazilian populations of Meloidogyne spp. Fund Appl Nematol 3:555-560

Carneiro RMDG, Almeida MRA, Quénéhervé P (2000) Enzyme phenotypes of Meloidogyne spp. populations. Nematology 2:645-654. https://doi.org/10.1163/156854100509510

De Ley P, Félix MA, Frisse LM, Nadler SA, Sternberg PW, Thomas WK (1999) Molecular and morphological characterization of two reproductively isolated species with mirror-image anatomy (Nematoda: Cephalobidae). Nematology 1:519-612. https://doi.org/10.1163/ 156854199508559

Golden AM, Birchfeild W (1965) Meloidogyne graminicola (Heterodera) a new species of root knot nematode from grass. Proc Helminthol Soc Wash 32:228-231

Hussey RS, Barker KR (1973) Comparison of methods for collecting inocula of Meloidogyne spp. including a new technique Plant Dis 57:1025-1028

Iqbal J, Zahra ST, Ahmad M, Shah AN, Hassan W (2018) Herbicidal potential of dryland plants on growth and tuber sproutingin purple nutsedge (Cyperus rotundus). Planta Daninha 36:e018170606. https://doi.org/10.1590/s0100-83582018360100001

Mantelin S, Bellafiore S, Kyndt T (2017) Meloidogyne graminicola: a major threat to rice agriculture. Mol Plant Pathol 18:3-15. https:// doi.org/10.1111/mpp.12394

Peerzada AM (2017) Biology, agricultural impact, and management of Cyperus rotundus L.: the world's most tenacious weed. Acta Physiol Plant 39(270). https://doi.org/10.1007/s11738-017-2574-7

Schmitz B, Bürgermeister W, Braasch H (1998) Molecular genetic classification of central European Meloidogyne chitwoodi and M. fallax populations. Nachrichtenblatt des Deutschen Pflanzenschutzdienstes 50:310-317

Webster TM, Nichols RL (2012) Changes in the prevalence of weed species in the major agronomic crops of the southern United States: $1994 / 1995$ to $2008 / 2009$. Weed Sci 60:145-157. https:// doi.org/10.1614/WS-D-11-00092.1 